\title{
TO THE QUESTION OF THE PECULIARITIES OF LEGAL REGULATION AND DISCIPLINARY RESPONSIBILITY UNDER THE CONDITIONS OF NEW ECONOMIC POLICY
}

\author{
Indira A. Shakirova ${ }^{1}$ \\ Robert R. Safin ${ }^{2}$ \\ Irina N. Fardeeva ${ }^{3}$ \\ Iskandar G. Mukhametgaliyev ${ }^{4}$
}

\begin{abstract}
The given article is devoted to the features of developing separate kinds of disciplinary liability in the period of new economic policy. Some features of legislative registration of a disciplinary responsibility in days of new economic policy and also during the specified period are analyzed. There was a formation of separate types of this responsibility: disciplinary responsibility on internal regulations, disciplinary responsibility on subordination and disciplinary responsibility of employees, according to the statutes on discipline and special provisions as a special type of disciplinary responsibility on subordination. The features of legal regulation of disciplinary responsibility,
\end{abstract}

considered in article, were of great importance in further development of institute of a disciplinary liability and the legislation on a disciplinary liability.The purpose of the given article is to comprehend the process of disciplinary liability institute's development on the basis of new achievements of legal science. Method or methodology of the work: modern methods of learning, special historical, comparative and legal methods were used. Results: scientific analysis of theoretical, historical and legal sources, determining the peculiarity and the content of disciplinary liability institute. Application of results: conclusions achieved as a result of scientific research can find practical application in law-

\footnotetext{
${ }^{1}$ Indira Abdulkhakovna Shakirova (main author), associate professor of the chair of constitutional, administrative and international law of the Naberezhnye Chelny Institute (branch) of Kazan Federal University, e-mail: indiraksu@mail.ru

${ }^{2}$ Kazan Federal University

${ }^{3}$ Kazan Federal University

${ }^{4}$ Kazan Federal University
} 
making activities of governmental institutions.

Keywords: disciplinary liability, legal regulation, new economic policy.

\section{Introduction}

In the theoretical aspect, the relevance of this problem is determined by the processes that took place in the Soviet state in the specified period of time and influenced on the content of the institution of disciplinary responsibility: the formation of the Soviet state and legal system, the content of socialist and Soviet ideology, and the implementation of a new economic policy.

These processes were accompanied by a critical revision of the state-legal phenomena that existed before the 1917 revolution. These factors determined the essence of the considered legal category and made it possible to distinguish its characteristics that are different from the corresponding qualities of disciplinary responsibility in other historical periods of the evolution of the Russian state [1].

Lawyers of the 20-ies in solving the problems of disciplinary responsibility were under the influence of the Soviet ideology. As a result, the legal phenomenon under study was turned into an attribute of the policy of the Soviet party, as a means of combating persons who do not share the rules of the Soviet community[2].

The authors, taking into account the historical conditions of the development of the Soviet state, created an entirely new institution of disciplinary responsibility in form and content, as well as law in general.

In a practical view, the need for this study is due to the confirmation of the concept of determining the right by legislation at specific historical stages of the evolution of the Russian state of various contents of the institution of disciplinary responsibility in ifferent historical epochs. Therefore, the correct understanding of the institution of disciplinary responsibility of the NEP period allows one to perceive the essence of this legal phenomenon objectively and at the present time.

\section{Materials and Methods}

The system of labor relations, which developed in the prerevolutionary Russian industry, underwent quite serious changes during 
the years of "war communism" and the NEP. At the same time, the problem of the struggle for improving labor discipline aroused serious concern of entrepreneurs and representatives of the factory administration in the late nineteenth and early twentieth centuries. It did not become less urgent after the proclamation of the "dictatorship of the proletariat".

The institute of disciplinary responsibility has passed a long way of its establishment and development. In the early Soviet period, prior to the adoption of the RSFSR Labor Code of 1918, disciplinary responsibility was regulated exclusively at the local level. It means that in individual enterprises by factory and plant committees or at general meetings of workers and employees, trade union bodies adopted the discipline statutes ("self-discipline"), the penal statutes for infringement labor discipline, provisions on labor discipline, the rules of labor discipline, instructions on the rules of internal regulations, etc., differing from each other not only by the title and status of the bodies that received them, but also the content.
At the same time, they all had a clear "anti-labor" direction and in the best of cases were taken with the opinion of the employer, excluded fines and more often dismissals from disciplinary penalties. It should be noted, that in 1918 the rules of the internal order were enacted on the initiative of the factory and factory committees, containing the specific set of disciplinary offenses and sanctions for their commition, [3, p. 34].

This experience can not be considered successful, since the specifics of production and the diversity of the manifestations of labor discipline, like its violations, made such formalization practically impossible. Later such attempts were adopted by the legislature and were justified by the scholars, but unfortunately this was not the result of success.

It was underlined in the statements and reports of economic, party and trade union bodies of the late $1920-1930$ 's that the relatively low labor productivity and the failure to meet the target figures were largely the result of a low level of labor discipline and a large number of violations of the Internal Regulations. The heads of enterprises in various regions and industries were also 
concerned with finding funds that would reduce the number of disciplinary violations in the workplace.

The great influence on the formation of the Soviet labor legislation was rendered by V.I. Lenin, who allowed "sharp forms of dictatorship" to impose labor discipline and he also demanded "the unconditional subordination to the single will for success in the process of work, organized as a large machine industry". He directly pointed out: "As for the punitive measures for nonobservance of labor discipline, they must be strict. We need a punishment up to imprisonment".

Dismissal from the factory can also be applied, but the nature of it is highly variable. Dismissal was a violation of the civil procedure during the capitalist system. However, in case of violation of labor discipline, especially concerning the labor service, the criminal "offense" had already been decided, and for that action a definite punishment must have been imposed.

For the purpose of improvement of labor discipline and labor productivity, comrades courts were organized in this period in accordance with the decree of November 14, 1919,
Decree "On workers of disciplinary comrades' courts". They dealt with the cases of violations commited by workers and employees of enterprises and establishments of labor discipline [4].

Comrades' courts were entitled to apply various penalties in respect of violating the labor discipline: reprimand with announcing on the enterprise; temporary deprivation of the right to participate in elections and the right to be elected to union organizations for a period not exceeding more then six months; temporary "shifting to the lowest post with payment at the lowest tariff rate" for a period of more than one month; sending on heavy "publiclynecessary" works with payment at the rate of executable work. In a case of repeated violation of labor discipline and in case of persistent non-compliance submit, dismissal took place with transferring to the terminal camp [5] .

If the court discovered signs of a criminal or civil offense, the case would refer to the appropriate courts. It is noteworthy that the initiator of bringing to court could be not only the administration, but also trade unions, created to protect the interests of employees. In changing and 
ISSN | 2179-7137 | http://periodicos.ufpb.br/ojs2/index.php/ged/index

supplementing the above-mentioned facts special Decree was introduced into the action "Regulations on disciplinary comrades' courts" of April 5, 1921, according to which the jurisdiction of disciplinary courts was extended. Thus, they received additional information on disciplinary offenses committed by the administrative and technical personnel and the top officials. The Art. 8 determined the number of concrete offenses considered by the Disciplinary Comrades' Court: delay in work; absence at work without reason; actions, distracting other employees from work; fulfilling of extraneous activity in the working time and some other. After the implementation of the Labor Code of the RSFSR of 1922 a similar category of special courts was liquidated."

The first question of elaborating the draft of a general provision on labor discipline was raised at the meeting of the Higher Council of the National Economy of the RSFSR on March 27, 1918, and on April, 1 of the same year the Presidium of the Supreme Economic Council considered the resolution on labor discipline submitted to the AUCCTU.
Unfortunately, the only provisions on labor discipline have not been worked out. Therefore, it was not accidentally that the Labor Code of the RSFSR of 1918 contained only a few laws to this account: firstly, the labor obligations of the employee were determined by clear and precise rules of the internal order, which should be worked out for enterprises and farms by trade unions and be approved by the labor department and contain, as far as possible, full instruction of the rules and the order of responsibility for the nonfulfillment of their duties (Article 124 of the Labor Code of the RSFSR); secondly, the dismissal of the employee was allowed in the event that the unreasonable norms of production were the result of his inferiority or gross negligence, which was carried out without warning (Article 119 of the RSFSR Labor Code).

It must be kept in mind that with a publicly-legal duty to work, in conditions of universal labor service, disciplinary dismissal, in a significant degree, was losing its punitive function. The Labor Code of the RSFSR of 1922 fixed a narrowing of state coercion spheres within the framework of the 
institute of disciplinary responsibility, proceeding from the legal equality of the parties to the contract of employment.

The rules of the internal regulations for individual enterprises were developed by agreement between their administration and the local department of trade unions. They were also approved by inspections of labor and contained an indication of the limits and the order of responsibility for their violation. The publication of the "Primary Rules of the Internal Order of the NCP of the RSFSR" was agreed upon with the AUCCTU and VSNH.

Uniformity of the types of disciplinary penalties and the grounds for their imposition of legislation did not exist. It should be noted here, that the history of the Soviet legislation on labor discipline and disciplinary responsibility attracted much attention from national research, but in various periods, the acts were placed differently, depending on the "line of the party"and the political conjuncture [6].

For the first time preliminary rules of the internal regulations of institutions, enterprises and farms were approved by the CNT of the USSR on 25 February 1924. A few basic violations of labor discipline had already been indicated in them. The concreteness of the elements of disciplinary offenses, the number of which reached 50 , and the sanctions for their implementation were enumerated in the penalty cards attached to the Primary Rules. The first table of executions was annexed to the Rules of the Internal Order for the enterprises of electricity and metalwork industry, approved by the NKT of the USSR on May 13, 1925.

The unfolded table of penalties was attached to the Primary rules of the internal order for industrial enterprises, it was the approved decision of the CNT of the USSR of July 19, 1927.

In the table of penalties, the disciplinary offenses were of exemplary nature and could be applied as analogy with other violations of labor discipline or be amended and supplemented by the administration in cooperation with trade union bodies.

Until 1930, in the Primary Rules and in the table of offenses, two types of penalties were usually imposed: reprimand with announcement by the department and notification of the FZMK and dismissal [7]. 
It was allowed to be involved, in agreement with the trade union organization, to the amenability in front of the court of production. In that period, the social assignment of labor law has so far been reflected at the level of both legislation and legal ideology.

As Y.A. Kantorovich states, the "general" principles of the compulsory law, calculated on the commodityproperty turnover, can not be applied to an employment contract without some changes and departures, since we have had something to do with property, but with the personality of a man who stands outside civil law, so he must be protected in his inalienable rights [88, p. 184] .

\section{Results and Discussion}

Taking into consideration the party and government decisions of the NEP period aimed at strengthening labor discipline, the authors differ in assessing their effectiveness.

Some pay attention to the excessive rigidity of the imposed measures of levy and their inconsistency with the severity of the violations committed by workers. Others give positive assessments of these initiatives "from above" and emphasize their effectiveness in combating with people's absence at the working place in the context of the mobilization of economy [9]. However, the latter draw in their conclusions, the tasks and slogans, relayed by the highest party leadership, and do not take into account the actual situation in which workers administrative and technical personnel of enterprises were compelled to comply with the decisions of the authorities [10]. In addition, the authors, as a rule, ignore the problems that arose in solving production problems that were the result of the implementation of these government initiatives.

\section{Conclusions}

Disciplinary responsibility during the NEP is an independent legal way of influencing workers and employees who committed a violation of labor discipline.

Disciplinary responsibility is the responsibility of workers and employees for the disciplinary offenses committed by them, exercised through the application of disciplinary sanctions by the head of the enterprise (institution), as well as by other officials whose list was established by the People's 
Commissariats (administrations) or

higher departments in order of subordination by bodies or persons. It was implemented by applying disciplinary sanctions to violators of labor discipline in accordance with the procedure established by law. Measures of social influence could also be applied to violators of labor discipline.

It is interesting to note here that under the violation of labor discipline, it was understood not all non-fulfillment by the workers and employees of their duties, but only illegal actions and, moreover, guilty ones. The illegal and guilty non-fulfillment of labor duties by the workers and employees is constituted as a disciplinary offense. Consequently, disciplinary responsibility was established for a disciplinary offense, that is for such an unlawful guilty violation of labor discipline, which, in terms of the degree of public danger did not entail criminal liability.

Disciplinary responsibility was necessarily presupposed by the subordination of the person who committed the offense to the person or authority imposing the penalty.

Disciplinary responsibility was implemented either in the manner

prescribed by the rules of internal labor regulations, or in the order of subordination. In certain branches of the national economy, the procedure for imposing disciplinary punishments was determined by special charters on discipline and on the basis of "special provisions".

In addition, the Soviet legislation was aware of disciplinary liability for special regulatory acts, for example, the responsibility of judges, the responsibility for violating the rules of fire protection and storage of official documents.

Thus, the transition from the policy of war communism to a new economic policy with all distinctness put on the agenda the question of the unification of state coercion within the institution of disciplinary responsibility.

\section{Acknowledgement}

The work is performed according to the Russian Government Program of Competitive Growth of Kazan Federal University.

\section{References}


McDaniel T. Autocracy, Modernization, and Revolution in Russia and Iran. Princeton (NJ.), 1991.

Shapiro L. The Origin of the Communist Autocracy. Cambridge, Mass., 1977. Part 3. P. 319, 320.

Shakirova I.A. Disciplinary responsibility for Soviet legislation during the New Economic Policy. Monograph. Krasnoyarsk, 2016. - 230p.

Gorsheunin, KP "Legal" regulation of labor of workers and employees in the first year of the Soviet power. - Moscow: Yurizdat, 1939. - 104 p.

Mikhayleenko N. T. Legal problems of labor discipline in the USSR. - Frunze: "Metektep", 1972. - 510 p.

The Modernization of Japan and Russia. A comparative study. N.Y.- L., 1975.

Shakirova I.A. Discipline of labor and disciplinary responsibility (historical and legal aspect) / / Science of Krasnoyarsk, 2016, No. 2. P. 62-70.
Kantorovich Y. A. Collective agreement. - L.: The publishing house of the Gubsoviet. of Leiningrad., 1924. - 190 p.

Eisenstadt S.N. Modernization: Protest and Change. Englewood Cliffs, 1966. Ch. 6-7.

Eisenstadt S.N. Tradition, Change and

Modernity. N.Y.- L., 1973 